\title{
PENERAPAN METODE QUALITY FUNCTION DEPLOYMENT (QFD) PADA PRODUK TEMPE (STUDI KASUS PADA PERUSAHAAN "SUMBER REJEKI")
}

Oleh:

\author{
NANING RETNOWATI *)
}

\begin{abstract}
ABSTRAK
Perusahaan tempe "Sumber Rejeki" sebagai pelaku bisnis harus bisa mencari, mengenal dan mengetahui kriteria atribut mutu apa saja untuk produk tempe yang dibutuhkan dan diinginkan oleh konsumennya. Salah satu metode yang terbukti efektif dan sukses untuk memenuhi kebutuhan dan keinginan konsumen adalah penggunaan aplikasi Quality Function Deployment (QFD).
\end{abstract}

Tujuan dari penelitian ini adalah : (1) untuk mengetahui kriteria atribut produk tempe yang dibutuhkan dan diharapkan oleh konsumen, (2) untuk mengetahui penilaian mutu produk tempe Sumber Rejeki dibandingkan produk kompetitor ("A" dan "B") dengan menggunakan metode QFD, dan (3) untuk mengetahui usaha perbaikan perusahaan Sumber Rejeki dengan menggunakan metode QFD agar produk yang dihasilkan sesuai dengan kebutuhan dan harapan konsumen.

Pada hasil penelitian didapatkan atribut harapan konsumen (whats) sebanyak sembilan (8) atribut. Dengan skala penilaian $1-5$, urutan prioritasnya : rasa tempe $(4,8)$, tekstur tempe $(4,67)$, warna tempe $(4,40)$, harga produk $(4,33)$, aroma tempe $(3,63)$, ketersediaan produk $(3,57)$, kemasan produk $(3,37)$, dan informasi produk $(3,33)$. Untuk penilaian kualitas produk tempe Sumber Rejeki, masih di bawah tempe "A", konsumen merasa kualitas produk yang diberikan belum sesuai dengan apa yang diharapkan. Produk tempe Sumber Rejeki mendapatkan penilaian kepuasan konsumen paling rendah pada hampir semua atribut kualitas produknya, bila dibandingkan dengan kompetitornya ("A") yaitu berupa rasa tempe $(4,27)$, aroma tempe $(4,63)$, ketersediaan produk $(4,23)$, kemasan produk $(4,20)$, tekstur tempe $(4,17)$ dan informasi produk $(4,27)$, dengan skala penilaian 1-5. Akan tetapi lebih tinggi dari tempe "B" pada atribut warna tempe $(4,37)$ dan harga produk $(4,40)$. Berdasarkan hasil perbandingan Performance Respon Teknis produk tempe Sumber Rejeki masih berada di bawah tempe "A". Perusahaan Sumber Rejeki perlu meningkatkan kinerja persyaratan respon teknis yang diperolehnya, dengan cara:(1) memperbaiki metode pada setiap tahapan proses pengolahan tempe; (2) memperbaiki desain kemasan produk; (3) memperbaiki strategi penetapan harga; (4) memperluas daerah distribusi; dan (5) meningkatkan strategi promosi.

Kata Kunci : Penilaian Konsumen, Kualitas Produk, Metode QFD (Quality Function Deployment) 


\section{PENDAHULUAN}

\subsection{Latar Belakang}

Tempe merupakan makanan yang amat dikenal oleh masyarakat Indonesia. Tempe merupakan makanan hasil fermentasi kacang kedelai dengan menggunakan jamur Rhizopus oligosporus dan Rhizopus oryzae. Tempe umumnya dibuat secara tradisional dan merupakan sumber protein nabati. Di Indonesia pembuatan tempe sudah menjadi industri rakyat (Francis F. J., 2000 dalam Suharyono A. S. dan Susilowati, 2006).

Indonesia merupakan negara produsen tempe terbesar di dunia dan menjadi pasar kedelai terbesar di Asia. Sebanyak 50\% dari konsumsi kedelai Indonesia diperoleh dalam bentuk tempe. Konsumsi tempe rata-rata pertahun di Indonesia saat ini sekitar 6,45 kg/orang. Sebagai sumber bahan pangan, tempe merupakan salah satu makanan pokok yang dibutuhkan oleh tubuh.

Saat ini permintaan konsumen lokal terhadap produk tempe semakin meningkat disebabkan semakin tingginya kesadaran masyarakat akan manfaat mengkonsumsi tempe bagi kesehatan. Peningkatan jumlah permintaan konsumen lokal terhadap produk tempe menjadi momentum yang tepat bagi perusahaan "Sumber Rejeki" untuk mengembangkan dan memperkuat pertumbuhan industri tempe yang sudah ada. Perkembangan konsumsi pada produk tempe perlu diperhatikan secara baik agar dapat dimanfaatkan secara maksimal untuk perkembangan pemasaran produk tempe.

Perusahaan Tempe "Sumber Rejeki" sebagai pelaku bisnis secara detail harus bisa mencari, mengenal dan mengetahui kriteria atribut apa saja untuk produk tempe yang dibutuhkan dan diinginkan oleh konsumennya. Salah satu metode yang terbukti efektif dan sukses untuk memenuhi kebutuhan dan keinginan konsumen adalah penggunaan aplikasi Quality Function Deployment (QFD).

Cohen (1995) mendefinisikan Quality Function Deployment (QFD) sebagai metode yang digunakan oleh perusahaan untuk mengantisipasi dan menentukan prioritas kebutuhan dan keinginan konsumen, serta menggabungkan kebutuhan dan keinginan tersebut ke dalam produk atau jasa yang disediakan bagi konsumen. Sedangkan definisi QFD menurut Parsaei dan Sullivan (1999), QFD adalah suatu pendekatan yang sistematis untuk memenuhi kebutuhan pelanggan dan secara tepat dihubungkan dengan desain teknik, rencana produksi dan proses produksi.

Metode QFD yang akan diterapkan di Perusahaan Tempe "Sumber Rejeki" merupakan QFD fase I yang dilakukan dengan penyusunan
House Of Quality (HOQ) yaitu berupa matriks yang berisi tentang kebutuhan konsumen yang lebih dikenal dengan Voice Of Customer (VOC) dan matriks berupa kebutuhan teknis dari pihak perusahaan. Melalui pendekatan QFD ini diharapkan akan dapat membantu Perusahaan Tempe "Sumber Rejeki" dalam menyusun prioritas perbaikan proses sehingga akan dapat menghasilkan produk tempe yang sesuai dengan keinginan dan kebutuhan konsumen.

\subsection{Perumusan Masalah}

Perumusan masalah yang dapat diidentifikasikan adalah :

a) Apakah kriteria atribut produk tempe yang diinginkan dan dibutuhkan oleh konsumen?

b) Bagaimanakah penilaian mutu produk tempe "Sumber Rejeki" dibandingkan produk kompetitor dengan menggunakan metode QFD?

c) Bagaimanakah usaha perbaikan Perusahaan Tempe "Sumber Rejeki" dengan menggunakan metode QFD agar produk tempe yang dihasilkan dapat sesuai dengan keinginan dan kebutuhan konsumen?

\subsection{Tujuan Penelitian}

Tujuan dari penelitian ini adalah:

a) Untuk mengetahui kriteria atribut produk tempe yang diinginkan dan dibutuhkan oleh konsumen.

b) Untuk mengetahui penilaian mutu produk tempe "Sumber Rejeki" dibandingkan produk kompetitor dengan menggunakan metode QFD.

c) Untuk mengetahui usaha perbaikan Perusahaan Tempe "Sumber Rejeki" dengan menggunakan metode QFD agar produk tempe yang dihasilkan dapat sesuai dengan keinginan dan kebutuhan konsumen.

\subsection{Manfaat Penelitian}

a). Manfaat bagi Perusahaan Tempe "Sumber Rejeki" antara lain adalah :

- Memberi informasi bagi perusahaan tentang penilaian mutu tempe dengan menggunakan metode QFD.

- Membantu perusahaan dalam menyusun prioritas perbaikan proses produksi agar dapat menghasilkan produk tempe yang 
sesuai dengan keinginan dan kebutuhan konsumen.

b). Manfaat bagi konsumen adalah : Produk tempe yang sesuai dengan keinginan dan kebutuhan konsumen akan dapat meningkatkan kepuasan konsumen dalam membeli produk.

\section{METODE PENELITIAN}

\subsection{Jenis Penelitian}

Jenis penelitian yang digunakan peneliti merupakan jenis penelitian deskriptif. Penelitian deskriptif dilakukan dengan cara mengumpulkan fakta-fakta dari suatu keadaan yang selanjutnya diuraikan atau dideskripsikan secara menyeluruh dan teliti. Pendekatan penelitian yang dilakukan adalah menggunakan mix methods, dimana metode kuantitatif merupakan pendekatan utama penelitian dan metode kualitatif disertakan untuk melengkapi dan mempertajam pembahasan hasil penelitian.

\subsection{Waktu dan Tempat Penelitian}

Penelitian dilakukan pada Bulan September - Desember 2012. Penelitian untuk memperoleh data primer dari responden konsumen akhir (end customer) akan dilakukan secara langsung di wilayah Kabupaten Jember.

Penelitian untuk memperoleh data primer dan sekunder mengenai proses pengolahan tempe "Sumber Rejeki" dan informasi pemasaran produk akan dilakukan di Perusahaan Tempe Sumber Rejeki yang berada di Jalan PB. Sudirman X/18 Jember.

\subsection{Batasan Masalah Penelitian}

Batasan masalah penelitian meliputi : Penelitian dilakukan dengan menggunakan metode QFD fase pertama, yaitu tahap Product Planning atau penyusunan Rumah Kualitas (House of Quality).

\subsection{Identifikasi Variabel}

Variabel yang menjadi perhatian pada penelitian ini adalah variabel bebas (independent) dan variabel tak bebas (dependent). Variabel bebas (independent) terdiri dari variabel kualitas produk tempe secara luas yang mencakup $4 \mathrm{P}$ (Product, Price, Place dan Promotion). Variabel tak bebas (dependent) yaitu berupa kemampuan teknis yang perlu dilakukan perusahaan agar dapat menghasilkan produk tempe yang sesuai dengan keinginan dan harapan konsumen.

\subsection{Pemilihan Responden}

\section{a). Responden Pakar}

Responden pakar yang dipilih terdiri dari pemilik dan karyawan pada perusahaan pengolah tempe yang berlokasi di Jember yakni perusahaan tempe Sumber Rejeki, "A" dan "B" yang banyak memiliki informasi tentang proses pengolahan dan pemasaran tempe.

\section{b). Responden Konsumen (End Customer)}

Responden konsumen yang dipilih adalah konsumen langsung (end customer) yang berdomisili di wilayah kota Kabupaten Jember. Pengambilan sampel dilakukan dengan menggunakan dua metode yaitu : metode proportional sampling dan metode purposive sampling.

1) Metode Proportional Sampling dilakukan dengan cara menyebarkan kuesioner di 3 Kecamatan di wilayah kota Kabupaten Jember, yaitu Kaliwates, Sumbersari, dan Patrang.

2) Metode Purposive Sampling.

Target responden end customer dengan metode purposive sampling ini bersifat spesifik. Pengambilan sample dilakukan dengan cara menyebarkan kuesioner dengan menggunakan teknik Sampling Accidental.

\subsection{Metode Pengumpulan Data}

a) Pengumpulan Data Primer

Data primer adalah data yang dikumpulkan sendiri secara langsung oleh peneliti dari obyek (lokasi) penelitian. Cara-cara yang digunakan untuk memperoleh data primer dengan interview/wawancara dan kuesioner

b) Pengumpulan Data Sekunder

Data sekunder digunakan untuk mendukung data-data primer yang diperoleh. Pengumpulan data dilakukan dengan teknik dokumentasi.

\subsection{Menyusun dan Menyebarkan Kuesioner}

Kuesioner disusun berdasarkan pertanyaan berkaitan dengan uji organoleptik dan kesukaan konsumen pada tempe serta unsur $4 \mathrm{P}$ (Product, Price, Place dan Promotion) yang penting dalam bauran pemasaran produk (pertanyaan berkaitan dengan variabel bebas dan tidak bebas). Penyusunan kuesioner dilanjutkan dengan penyebaran kuesioner kepada end customer.

\subsection{Uji Validitas dan Reliabilitas Instrumen}

Agar instrumen yang dipakai dalam penelitian ini dapat berfungsi sebagaimana yang 
diharapkan,maka instrumen tersebut perlu diuji validitas dan reliabilitasnya. Uji validitas dan reliabilitas dilakukan melalui uji statistik dengan menggunakan software SPSS 16.0.

\subsection{Analisa Data}

Analisa data dilakukan dengan menyusun House Of Quality yang ditunjukkan dalam gambar matrik pada Gambar 1. House of Quality yang disusun merupakan Fase I dari Metode Quality Function Deployment (QFD) meliputi langkah-langkah sebagai berikut :

1) Pendataan Keinginan dan Kebutuhan Konsumen (Customer Requirements/Whats) / Penyusunan Matriks Whats.

Berisi tentang variabel-variabel produk tempe yang menjadi kebutuhan dan keinginan konsumen.

2) Pendataan Technical Requirements/Technical Description (Hows) / Penyusunan Matriks Whats.Technical Requirements /Technical Description (karakteristik teknis) yang diperoleh dari diskusi bersama dengan praktisi perusahaan. Setiap karakteristik yang ada harus berhubungan secara langsung dengan customer requirements dan dapat diukur.

3) Mengembangkan matriks hubungan antara keinginan konsumen (Customer Requirements/Whats) dengan kebutuhan teknis (Technical Requirements/Hows) atau disebut dengan Relationship.

Matriks hubungan ini merupakan interaksi antara Technical Requirements dengan Customer Requirements untuk menunjukkan kuat atau lemahnya hubungan tersebut yang dinotasikan dalam bentuk tanda/simbol dengan bobot angka yang berbeda sebagai berikut :

a) Simbol [•] menyatakan hubungan kepentingan sangat kuat dan diberi bobot 9

b) Simbol [o] menyatakan terdapat hubungan kepentingan yang tidak terlalu kuat dan diberi bobot 3

c) Simbol $[\Delta]$ menyatakan hubungan kepentingan lemah dan diberi bobot 1

d) Tanpa simbol menyatakan tidak adanya hubungan kepentingan dan diberi bobot 0 .

4) Mengembangkan Matriks Hubungan diantara Technical Requirements/Hows (Co-Relationship).

Matriks ini terletak pada bagian atap yang diisikan angka-angka yang akan menggambarkan hubungan atau pengaruh dari Technical Requirements yang satu dengan yang lain. Matriks ini menunjukkan adanya hubungan positif kuat, positif lemah, negatif kuat, negatif lemah atau sama sekali tidak ada hubungan antara Technical Requirements satu terhadap Technical Requirements lainnya. Simbolsimbol yang digunakan dalam memetakan korelasi antara Technical Requirements, yaitu:

a) Korelasi positif kuat dengan simbol ++

b) Korelasi positif dengan simbol +

c) Korelasi negatif kuat dengan simbol --

d) Korelasi negatif lemah dengan simbol -

5) Penyusunan Matriks Perencanaan

Pada matriks perencanaan ini berisi tentang informasi penting, sebagai tempat penentu sasaran/tujuan produk, tahapannya meliputi sebagai berikut :

a) Penentuan Sub Matriks Tingkat Kepentingan (Importance to Customer)

Sub matriks ini berisi tentang nilai-nilai kepentingan konsumen terhadap produk tempe yang diperoleh dari penyebaran kuesioner.

b) Penentuan Sub Matriks Tingkat Kepuasan Konsumen (Customer Satisfaction Performance).

Merupakan suatu penilaian dari konsumen terhadap kualitas produk tempe Perusahaan Tempe "Sumber Rejeki" dibandingkan dengan produk kompetitor.

c) Penentuan Sub Matriks Nilai Target (Goal) Menyatakan seberapa besar tingkat kinerja kepuasan yang diharapkan dapat dicapai oleh perusahaan untuk memenuhi setiap keinginan konsumen. Goal ditetapkan dari perbandingan nilai terbaik tingkat kepuasan produk tempe Perusahaan "Sumber Rejeki" dengan kompetitornya.

d) Penyusunan Sub Matriks Sales Point Sub matriks ini berisi tentang tingkat penjualan produk yang diinginkan oleh perusahaan (Perusahaan Tempe "Sumber Rejeki") berdasarkan importance to customer. Nilai yang dipakai adalah 1 (no sales point), 1.2 (medium sales point), 1.5 (strong sales point).

e) Penyusunan Sub Matriks Improvement Ratio Sub matriks ini berisi tentang nilai dari setiap customer requirements yang didapatkan dari pembagian antara target value (goal) dengan customer satisfaction performance terhadap produk tempe "Sumber Rejeki".

f) Penyusunan Sub Matriks Raw Weight Sub matriks ini berisi tentang nilai dari setiap customer requirements yang didapatkan dengan cara : importance to customer $\mathrm{x}$ 
improvement ratio $\mathrm{x}$ sales point.

g) Penyusunan Sub Matriks Bobot Normal (Normalized Raw Weight)

Bagian ini berisi nilai bobot perhitungan dari data yang dibuat selama matrik perencanaan. Nilai dari bobot normal adalah raw weight dibagi jumlah raw weight.

6) Matriks Teknis

Pada bagian ini berisi empat jenis data yaitu meliputi :

a) Bobot Respon Teknis

Nilai dari bobot respon teknis adalah normalized raw weight $\mathrm{x}$ numeric matrik relationship.

b) Prioritas

Nilai prioritas mempresentasikan konstribusi relatif dari respon teknis terhadap kepuasan konsumen. Semakin besar nilai prioritas maka semakin besar pula kontribusi respon teknis tersebut dalam memenuhi kepuasan konsumen.

c) Perbandingan Kinerja Proses Kompetitor (Benchmarking)

Dalam menentukan penilaian kualitas produk, cara yang digunakan adalah dengan melakukan benchmarking dengan pesaing. Benchmarking bertujuan mengukur produk pesaing untuk dibandingkan dengan produk sendiri (Tempe "Sumber Rejeki").

Benchmarking $=$

¿(Kinerja Produk (kepuasan customer) xNilai hubungan whats dan hows

ENilai hubungan whats dan hows

d) Target

Target yang ingin dicapai oleh pihak perusahaan, didapat dari nilai terbaik antara nilai Own Performance dan Competitive Performance.

\section{HASIL DAN PEMBAHASAN}

\subsection{Analisis Produk Tempe Sumber Rejeki Dengan Metode QFD}

Metode Quality Function Deployment (QFD) perlu diimplementasikan pihak Perusahaan Sumber Rejeki agar dapat membandingkan kualitas produk tempe yang diproduksinya dengan produk kompetitornya. Analisis metode QFD selengkapnya dapat dilihat pada Gambar 1, yaitu gambar House Of Quality (HOQ) secara utuh. Gambar ini mewakili keenam matriks yaitu matrik harapan konsumen/pelanggan (whats), matrik respon teknis (hows), matrik korelasi whats dan hows, matrik korelasi respon teknis, matrik perencanaan (sub matriks importance to customer, customer satisfaction, goal, sales point, improvement ratio, dan raw weight), dan matrik teknis ( prioritas, benchmarking, target). Dari gambar analisis QFD secara keseluruhan yang dihasilkan dapat digunakan untuk mengidentifikasi, mengkomunikasikan, dan menerapkan sistem secara keseluruhan dalam meningkatkan kualitas produk. Dengan metode ini, perusahaan Sumber Rejeki akan dapat mengetahui penilaian konsumen terhadap kualitas produknya bila dibandingkan dengan kompetitornya. Selain itu perusahaan Sumber Rejeki akan dapat meningkatkan kualitas produk tempe (secara luas) sehingga dapat sesuai dengan harapan dan keinginan konsumennya, dan akhirnya akan dapat meningkatkan kepuasan konsumen.

\subsection{Menyusun Persyaratan Konsumen (Matriks Whats)}

Hal penting bagi konsumen yang perlu diperhatikan dalam memilih produk tempe meliputi : (a) unsur organoleptik tempe, (b) kemasan produk; (c) harga produk, (d) ketersediaan produk dan (d) informasi produk. Unsur organoleptik tempe berkaitan dengan cita rasa tempe yang diinginkan dan diharapkan oleh konsumen, antara lain mencakup: (1) warna tempe, (2) aroma tempe, (3) rasa tempe, dan (4) tekstur tempe.

\subsection{Menyusun Persyaratan Teknik (Matriks Respon Teknis/Hows)}

Matriks respon teknis (hows) berisi tentang beberapa atribut karakteristik teknis (kebutuhan teknis) yang perlu dilakukan perusahaan. Matriks respon teknis diperoleh dengan cara menterjemahkan harapan atau keinginan pelanggan (whats) ke dalam bentuk karakteristik pengembangan produk yang perlu dilakukan perusahaan sehingga dapat memenuhi harapan dan keinginan konsumen. Hasil wawancara dan observasi yang telah dilakukan diperoleh sembilan (14) atribut respon teknis yaitu: pemilihan bahan baku (biji kedelai), perebusan I, perendaman I, penggilingan, pemisahan kulit ari kedelai, perendaman II, perebusan II, penirisan dan pendinginan, penginokulasian (peragian), pengemasan, fermentasi, strategi penetapan harga, strategi distribusi, dan strategi promosi. 


\subsection{Mengembangkan Matriks Perencanaan}

Matriks perencanaan berisi tentang informasi penting sebagai tempat penentu sasaran/tujuan produk. Matriks perencanaan terdiri dari beberapa sub matriks diantaranya: sub matriks importance to customer, customer satisfaction performance, goal, sales point, improvement ratio, raw weight, dan normalized raw weight.

\subsubsection{Mengembangkan Prioritas Persyaratan Konsumen (Sub Matriks Importance to Customer)}

Nilai atribut harapan konsumen (whats) yang mendapatkan prioritas tertinggi yaitu rasa tempe selanjutnya diikuti oleh tekstur tempe, warna tempe, harga produk, aroma tempe, ketersediaan produk, kemasan produk, dan informasi produk.

\subsubsection{Penilaian Kompetitif Konsumen (Sub Matriks Customer Satisfaction Performance / Tingkat Kepuasan Konsumen)}

Penilaian konsumen terhadap tekstur tempe Sumber Rejeki lebih rendah dibanding produk pesaingnya. Tingkat kerapatan miselium jamur Rhizopus sp. pada tempe Sumber Rejeki dianggap lebih rendah dibanding kedua pesaingnya maka dari itu memiliki nilai yang paling rendah diantara tempe lainnya. Sedangkan nilai atribut kualitas tempe yang lain seperti : warna tempe, aroma tempe, rasa tempe, kemasan produk, harga produk, ketersediaan produk dan informasi produk berada di bawah perusahaan " $A$ " namun berada di atas perusahaan " $B$ ". Hal tersebut menunjukkan bahwa ketujuh atribut kualitas tempe Sumber Rejeki oleh konsumen dirasakan lebih baik dibandingkan perusahaan " $\mathrm{B}$ ".

\subsubsection{Sub Matriks Goal (Sasaran)}

Nilai goal pada enam atribut kualitas produk yang meliputi : aroma tempe, rasa tempe, tekstur tempe, kemasan produk, ketersediaan produk dan informasi produk perusahaan Sumber Rejeki berada dibawah kedua pesaingnya, berarti pihak perusahaan Sumber Rejeki harus berusaha keras untuk mencapai nilai goal yang ditargetkan agar dapat memenuhi keinginan dan harapan konsumennya.

\subsubsection{Sub Matriks Sales Point (Titik penjualan)}

Atribut yang mendapatkan nilai titik penjualan kuat $(1,5)$ yaitu warna tempe, rasa tempe, tekstur tempe dan harga produk, berarti konsumen menganggap bahwa keempat atribut kualitas tersebut sangat berperan dalam pengambilan keputusan pembelian. Titik penjualan (sales point) menengah $(1,2)$ terdapat pada atribut aroma tempe dan ketersediaan produk. Kedua atribut kualitas tersebut merupakan prioritas kedua bagi konsumen dalam membeli produk tempe. Sedangkan titik penjualan lemah $(1,0)$ meliputi : kemasan produk dan informasi produk, menunjukkan bahwa kedua atribut kualitas tersebut menjadi prioritas terakhir bagi konsumen dalam membeli produk tempe.

\subsubsection{Sub Matriks Improvement Ratio (Rasio Perbaikan)}

Nilai improvement ratio dari urutan tertinggi hingga terendah meliputi : rasa tempe, kemasan produk, tekstur tempe, aroma tempe, informasi produk, ketersediaan produk, warna tempe dan harga produk.

\subsection{Mengembangkan Prioritas Persyaratan Teknik (Matriks Teknik)}

Matriks teknis merupakan matrik yang dapat digunakan untuk menentukan urutan prioritas respon teknis dan untuk mengetahui hasil perbandingan dari kinerja respon teknis suatu perusahaan bila dibandingkan dengan perusahaan pesaingnya. Matrik teknis terdiri dari sub matriks bobot respon teknis, prioritas dan benchmarking.

\subsubsection{Sub Matriks Prioritas}

Atribut respon teknis yang memiliki bobot di atas rata-rata adalah : pemilihan bahan baku dengan nilai 5,35; penginokulasian dengan nilai 5,35; fermentasi dengan nilai 5,35; perendaman II dengan nilai 4; perebusan II dengan nilai 4; dan pengemasan dengan nilai 3,52 . Prioritas satu sampai tiga memiliki bobot di atas rata-rata maka dari itu harus lebih diutamakan karena berperan penting dalam penentuan kualitas produk tempe.

\subsubsection{Sub Matriks Benchmarking (Ukuran Perbandingan Kualitas)}

Produk tempe Sumber Rejeki masih berada di bawah kedua pesaingnya, hal ini dapat dilihat dari nilai hasil perbandingan performance meliputi : atribut perebusan I, perendaman I, penggilingan, pemisahan kulit ari kedelai, serta penirisan dan pendinginan. Penilaian diatas menunjukkan bahwa perusahaan Sumber Rejeki perlu meningkatkan kinerja persyaratan respon teknis yang diperolehnya, dengan cara berusaha mencapai target yang sama atau melebihi kompetitor agar dapat menghasilkan produk yang sesuai dengan keinginan konsumen. 


\subsubsection{Sub Matriks Target}

Semua nilai perbandingan performance setiap atribut respon teknis produk tempe Sumber Rejeki lebih kecil dari nilai target, sehingga semua respon teknis perlu ditingkatkan. Nilai target pada semua atribut respon teknis merupakan nilai performance respon teknis yang dimiliki produk "A", berarti perusahaan ini telah menerapkan strategi perbaikan kualitas produk dan strategi pemasaran yang baik.

\section{KESIMPULAN DAN SARAN}

\subsection{KESIMPULAN}

1) Atribut harapan konsumen (whats) pada produk tempe terdiri dari delapan (8) atribut, dengan urutan prioritas sebagai berikut : rasa tempe $(4,8)$, tekstur tempe $(4,67)$, warna tempe $(4,40)$, harga produk $(4,33)$, aroma tempe $(3,63)$, ketersediaan produk $(3,57)$, kemasan produk $(3,37)$, dan informasi produk $(3,33)$.

2) Nilai kualitas produk tempe Sumber Rejeki berdasarkan persepsi penilaian konsumen mengenai tingkat kepuasan, berada di atas tempe " $\mathrm{A}$ " dan "B" untuk atribut warna tempe dan harga produk. Atribut rasa tempe, aroma tempe, kemasan produk, ketersediaan produk dan informasi produk tempe Sumber Rejeki berada di bawah produk tempe "A". Atribut tekstur tempe Sumber Rejeki juga berada di bawah tempe "B".

3) Berdasarkan hasil perbandingan Performance Respon Teknis produk menunjukkan bahwa produk tempe Sumber Rejeki masih berada di bawah produk tempe "A". Penilaian diatas menunjukkan perusahaan Sumber Rejeki perlu meningkatkan kinerja persyaratan respon teknis.

\subsection{SARAN}

1) Perusahaan Sumber Rejeki dalam usaha mempertahankan eksistensi usahanya harus senantiasa melakukan perbaikan kualitas produknya.

2) Perusahaan Sumber Rejeki perlu menjalin kerjasama/mitra misal dengan pihak Bank agar dapat meningkatkan kualitas produknya.

\section{DAFTAR PUSTAKA}

Ali, I, 2008. Buat Tempe Yиииик. http://iqbalali.com/2008/05/07/buattempe-yuuuuk/. Diakses tanggal 18 September 2012.

Arikunto, S. 2002. Prosedur Penelitian Sebuah Pendekatan Praktis. Jakarta: PT. Bina Aksara.

Astawan, M. 2008. Sehat Dengan Tempe.Panduan Lengkap Menjaga Kesehatan dengan Tempe. Jakarta: PT Dian Rakyat.

Cohen, L. 1995. Quality Function Deployment, How to Make QFD Work for You. Massachussetts: Addison Wesley Publishing Company.

Ferlina, F. $2009 . \quad$ Tempe. http://www.adln.lib.unair.ac.id/go.php. (Diakses pada tanggal 2 Oktober 2009).

Hidayat, N. 2008. Fermentasi Tempe. http://ptp2007.files.wordpress.com/2008/ 03/fermentasi-tempe.pdf. (Diakses pada tanggal 20 Oktober 2009).

Kartika, B. P. Hastuti, W. Supartono. 2000. Pedoman Uji Inderawi Bahan Pangan. Yogyakarta: UGM Press.

Kasmidjo, R.B., 1999. TEMPE : Mikrobiologi dan Kimia Pengolahan serta Pemanfaatannya. Yogyakarta : PAU Pangan dan Gizi UGM.

Kotler, P. 2003. Marketing Management, Eleventh Edition. USA : Prentice Hall.

Lubis, A. N. 2004. Peran Distribusi. Medan: Fakultas Ekonomi Universitas Sumatera Utara.

Nurbiyati, T dan Machfoedz, M. 2005. Manajemen Pemasaran Kontemporer. Yogyakarta: Penerbit Kanyon.

Sugiyono. 2001. Metode Penelitian Bisnis.

Bandung: Penerbit Alfabeta.

Suharyono, A. S. dan Susilowati. 2006. Pengaruh Jenis Tempe dan Bahan Pengikat Terhadap Sifat Kimia dan Organoleptik 
Produk Nugget Tempe. Prosiding Seminar Hasil-hasil Penelitian dan Pengabdian Kepada Masyarakat, Universitas Lampung, 2006, hal 280-290. http://lemlit.unila.ac.id/file/Prosiding/Pros idingI2006.pdf (Diakses pada tanggal 17 November 2009).
Tandjung, J.W. 2004. Marketing Management. Pendekatan Pada Nilai-nilai Pelanggan. Malang: Bayu Media.

Winarno, F.G. 2002. Kimia Pangan dan Gizi. Jakarta: PT. Gramedia Pustaka Utama. 